\title{
DEGREE OF THREAT TO THE BIOLOGICAL DIVERSITY IN THE ILHA GRANDE STATE PARK (RJ) AND GUIDELINES FOR CONSERVATION
}

\author{
ALHO, C. J. R., ${ }^{1}$ SCHNEIDER, M. ${ }^{2}$ and VASCONCELLOS, L. A. ${ }^{3}$ \\ ${ }^{1}$ Universidade de Brasília, SHIS QL 6, conj. 3, casa 13, CEP 71620-035, \\ Brasília, DF, Brazil \\ ${ }^{2}$ Universidade Federal do Rio Grande do Sul, e-mail: mschnei@ vortex.ufrgs.br \\ 3e-mail: luisasv@terra.com.br \\ Correspondence to: Cleber J. R. Alho, SHIS QL 6, conj. 3, casa 13, CEP 71620-035, \\ Brasília, DF, Brazil, e-mail: alho@unb.br \\ Received August 2, 2001 - Accepted August 17, 2001 - Distributed August 31, 2002
}

(With 6 figures)

\begin{abstract}
The State Park of Ilha Grande is only a part (5,594 hectares) of the entire island (19,300 hectares) which is located off the south coast of Rio de Janeiro state, between the cities of Mangaratiba and Angra dos Reis. Approximately half of the Park area (47\%) is covered by dense Atlantic forest. The secondary forest growth is in a process of ecological succession close to attaining maturity (43\%) and the remaining part (10\%) is composed of human-altered areas (1\%), rocky outcrops with herbaceous vegetation (7\%), mangroves and beaches (2\%). The fauna is well represented but already shows signs of degradation with introduced species. The analysis of the degree of threat has shown that the dense forest habitat has a relatively stable status of conservation while the secondary forest, the mangrove and the herbaceous vegetation on rocky outcrops (and their fauna) are categorized as vulnerable. The area altered by human occupation is considered threatened. Since the coastal area where Ilha Grande is located is well known for its beautiful scenery (known as the green coast, because of the contrast between the ocean and the Atlantic forest covering the Serra do Mar mountain chain). There is a strong possibility for tourism to become the means in which to achieve economic sustainability for conservation. Contradictorily, tourism is also the major threat to local biodiversity and its landscape units. Because tourism is not organized and controlled, during high season the numbers grow above local capacity, giving rise to a proliferation of hotels, guesthouses and camping grounds. The resulting untreated open sewage, random garbage disposal and other harmful activities form the major threats to biodiversity.
\end{abstract}

Key words: biodiversity, conservation, degree of threat, habitats, Ilha Grande, pollution, tourism.

\section{RESUMO}

Parque Estadual da Ilha Grande - ameaças ambientais e diretrizes para conservação

O Parque Estadual da Ilha Grande é somente uma parte (5.594 hectares) de toda a ilha (19.300 hectares) localizada na costa sul do Estado do Rio de Janeiro, entre as cidades de Mangaratiba e Angra dos Reis. Aproximadamente a metade da área do Parque (47\%) é coberta por floresta densa, ombrófila, de Mata Atlântica. A mata secundária, em processo de regeneração por sucessão ecológica, está perto da maturidade (43\%) e o restante (10\%) é composto por áreas antropizadas (1\%), afloramentos rochosos com vegetação herbácea (7\%), restingas, manguezais e praias (2\%). A fauna está bem representada, mas já mostra sinais de degradação com a presença de espécies introduzidas. A análise conduzida sobre o grau de ameaças mostrou que a floresta ombrófila densa está relativamente bem conservada, enquanto a mata secundária, as restingas e mangues e a vegetação herbácea dos terrenos rochosos (e suas respectivas faunas) estão categorizadas como vulneráveis. A área onde há ocupação humana é categorizada como ameaçada. Contraditoriamente, a maior ameaça à biodiversidade local em suas 
unidades de paisagens é o turismo. Uma vez que a costa onde se localiza a Ilha Grande tem alto valor cênico (conhecida como costa verde pelo constraste entre o mar e o verde da Mata Atlântica que cobre a Serra do Mar), o turismo tem alto potencial para se tornar o meio de atingir a sustentabilidade econômica para conservação. No entanto, por causa do turismo desorganizado e sem controle hoje em prática, com visitantes em número superior à capacidade de suporte na alta estação, a proliferação de hotéis, pousadas e acampamentos e o consequiente esgoto a céu aberto, depósito de lixo e outras atividades prejudiciais à biodiversidade são as principais ameaças.

Palavras-chave: biodiversidade, conservação, grau de ameaça, habitats, Ilha Grande, poluição, turismo.

\section{INTRODUCTION}

The State Park of Ilha Grande was created by decree of the Governor of Rio de Janeiro (Decreto 15273 of 28 June, 1971), aiming to protect the local biodiversity as well as to sti- mulate tourist activities. The Park of 5,594 hectares is located in the area facing the open ocean of the island, where a former penitentiary used to be active and where the State University of Rio de Janeiro (UERJ) currently has some field facilities for research (Fig. 1).

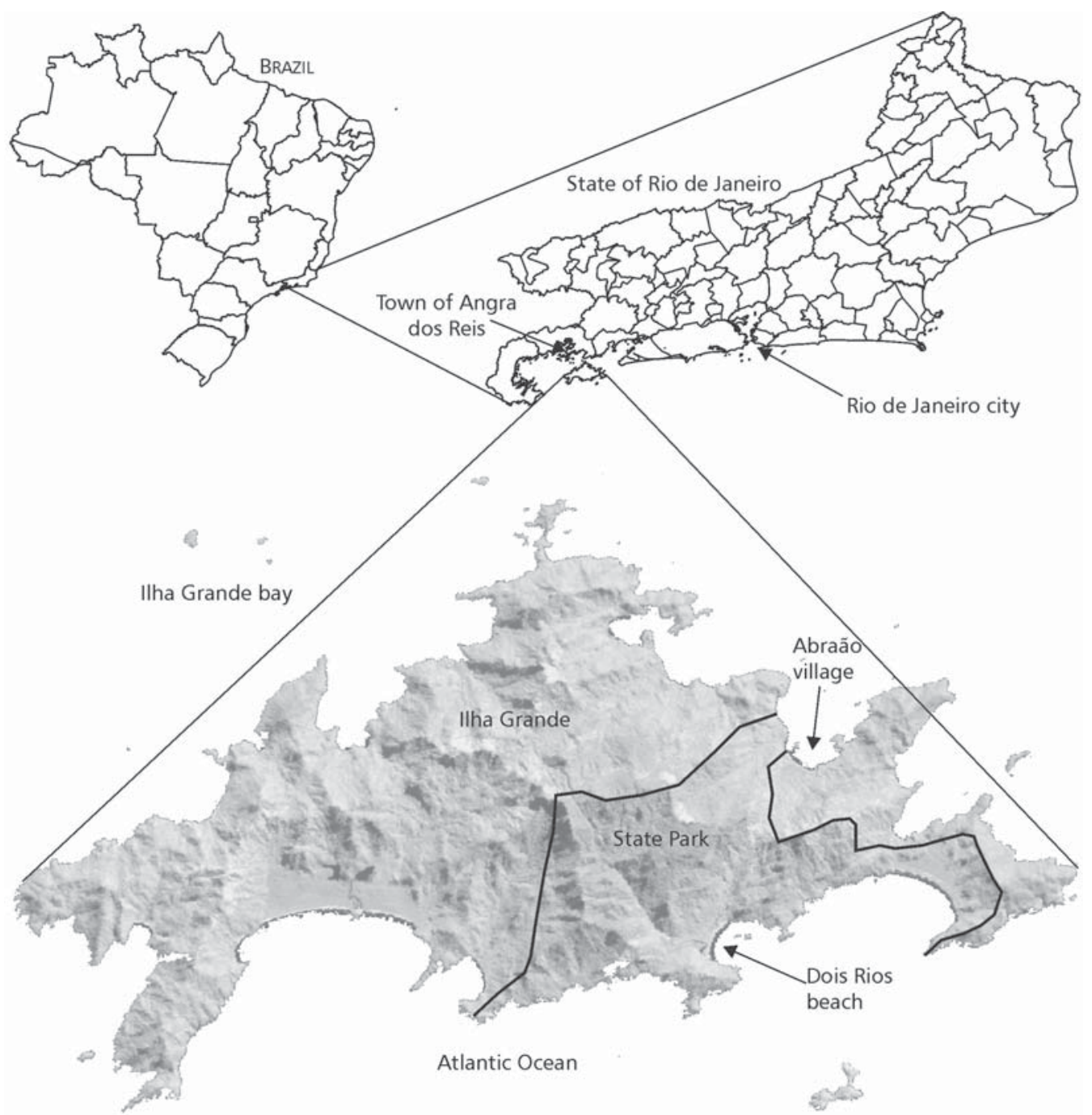

Fig. 1 - The location of the study area on Ilha Grande and in its state park. 
The whole island of Ilha Grande is an officially declared protected area, according to the state constitution of Rio de Janeiro (Article 266). The island measures $28 \mathrm{~km}$ east-west and $12 \mathrm{~km}$ north south with an area of 19,300 hectares. The relief is hilly; with its peak on the top of Serra do Retiro (1,030 meters) and Bico do Papagaio (959 meters). Rivers and creeks come down the mountains and form small falls. The vegetation is part of the Atlantic forest covering the Serra do Mar from which the island separated in the past.

Human occupation of the island is deep-rooted, as in the past the Ilha Grande bay was used for intense trade and the port on the island, named "Freguezia de Santana da Ilha de Fora", was intensively used until the year 1850 (UFRRJ/IEF/PRO-NATURA, 1992). According to this report, the island was also used as an initial port for the slave trade.

The major objective of this study is to identify the dominant landscape units (natural habitats) of the State Park of Ilha Grande and to apply a threat analysis in order to interpret and propose guidelines to conserve the local biodiversity through sustainable use of high potential tourism.

\section{METHODS}

Research was conducted in the Ilha Grande State Park (5,594 hectares), extending the observation throughout the whole island $(19,300$ hectares) located off the south coast of Rio de Janeiro state, Brazil. Four 10-day field trips were carried out (January, June and September of 1998 and January of 1999). Random transects were established, using mostly existing trails spread over the Park, with at least two researchers going on foot to survey the landscape units and animals, covering the focal study area including all types of habitats. In each habitat the characteristics of the vegetation cover as well as the animal survey were recorded on specific field sheets. Transecting all the habitats by hiking at a good pace along the trails, when possible, and where none existed we aimed for a specific point, crossing the forest. During a six-hour journey we could cover about 4-7 kilometers.

In addition, other sources of information were used to assess the identification of the habitats and their associated fauna, relying particularly on the Park's Management Plan report. We also searched for local reports believed likely to contain relevant information, such as reports on environmental issues, supported by the federal Ministry of the Environment for the municipality of Angra dos Reis, to be carried out in Ilha Grande, a project known as PED, Projeto de Execução Descentralizado (PED, 1998). We also examined the IBGE (Brazilian Institute of Geography and Statistics) maps SF.23-Z-C for the municipalities of Angra dos Reis (including Ilha Grande), Parati and Cunha, interpreting them with the help of the satellite images of the NGO SOS Mata Atlântica, for the evolution of deforestation in the period 1990-1995 (SOS Mata Atlântica, INPE and ISA, 1998; Garrod \& Willis, 1994).

To evaluate the habitat quality of the Park we applied a methodology used by Hannah et al. (1995) who proposed the following equation:

$$
\text { Habitat index }=\frac{\begin{array}{c}
\text { Non disturbed area }+0.25 \\
\text { (Partially disturbed area) } \times 100
\end{array}}{\text { Total area }}
$$

We considered all the pristine dense Atlantic forest as undisturbed area. The other categories were summed up and considered as partially disturbed.

To analyze the degree of threat to the natural environment we considered the seven types of landscape unit as described by the Park's management plan (UFRRJ/IEF/PRO-NATURA, 1992) and the field observations adapting the methods used by WWF, according to Olson \& Dinerstein (1994). For each habitat type four kinds of threats are evaluated, relying on the present scientific knowledge: overexploitation, pollution, disturbed habitat and altered substrate. A value is attributed to the importance that each specific threat has for the given habitat. The total value is converted into conservation status (critical, threatened, vulnerable, relatively stable and relatively intact). Biodiversity was studied as indicator species, relying mainly on birds and mammals. The concept of indicator species is based on occurring species in the study area and subject to some environmental impact in the past or in the present, resulting in intolerant species or communities to the impact or some tolerant species, which take advantage of the given altered environmental condition.

The number of visitors in Ilha Grande, during the peak season (December, January and February) was estimated by checking the number of tickets sold by the collective transportation by boat (CONERJ) from the cities of Mangaratiba and Angra dos Reis to the village Abraão on the island. In addition, we interviewed local residents, guesthouse owners, local 
NGOs such as "Brigada Mirim Ecológica" to better understand the flow of visitors, disposal of litter and existing open sewage on the island.

\section{RESULTS}

Natural Habitats. The following landscape units or natural habitats are present in the Park: Dense Atlantic Forest (Floresta Ombrófila Densa), Secondary Forest (Mata Secundária), Herbaceous Vegetation on rocky outcrop (Vegetação Herbácea em afloramento rochoso), Sandy ridges (Restinga), Mangroves (Manguezal) and Beaches (Praias).

The pristine forest (dense Atlantic forest) covers the center of the island, at elevations of over 400 meters, comprising $46.7 \%$ of the Park. It is well preserved thanks to two reasons: because human access is difficult and because the southern moist sea winds favor rapid forest regeneration and maintenance. The precipitation in the region is 1,234 mm with an average of 123 rainy days per year (UFRRJ/IEF/PRO-NATURA, 1992). Its high canopy is about 25-30 meters in height with some emergent trees reaching 40 meters, but the average canopy is about $15 \mathrm{~m}$ high. The tree diameter at breast height $(\mathrm{DBH})$ is around 1 meter with clean understory, allowing the observer to walk through it. However, some studies point out that selective logging occurred in the island to exploit the most valuable trees (Maciel et al., 1984).

The secondary forest covers the second largest part of the Park (43.2\%), with the canopy height reaching about 15 meters and 20 meters in some areas. The DBH is of 20-30 meters, indicating an advanced stage of ecological succession. In the denser secondary forest such as in the area between Dois Rios and Parnaioca, this forest looks like a mature dense forest. In both mature and secondary forest flowering trees can be seen, such as the "guapuruvu" Schizolobium parahyba, the "jacatirão" Tibouchina sp., the "ipês" Tabebuia spp., Vochysia sp. and Cybistax sp. The "sapucaia vermelha" Lecythis pinsonis seems to be in flower when it has its new reddish shoots.

The sandy ridges and mangroves (comprising respectively $1.3 \%$ and $0.3 \%$ ) are located in small areas, near the beaches of Lopes Mendes and Dois Rios. Small trees, scrub communities and ground cover plants form the sandy ridge vegetation such as the palm Allagoptera arenosa. The mangrove is located in the lower area where the rivers drain into the sea. There are typical mangrove species such as the "mangue vermelho" Rhizophora magle, the "mangue branco" Laguncularia racemosa and the "siriúba" Aviccenia schaueriana. In the transition zone between the mangrove and the forest occurs the "algodão-da-praia" Hibiscus pernambu.

The beaches are formed of white sand. Lopes Mendes beach is $3 \mathrm{~km}$ long and just behind it there is restinga (sandy ridges) vegetation. The following beaches are in the domain of the Park: Praia Preta, Praia do Santo Antônio, Dois Rios and Praia Brava. However, the Park also claims that the following beaches are in its area: Praia do Abraão, Praia Grande das Palmas, Praia dos Mangues and Praia Parnioca.

The vegetation is well documented in the Park Management Directive Plan (UFRRJ/IEF/PRONATURA, 1992). Our field work was able to observe the degree of degradation in some focal areas such as the Córrego do Bicão, behind Abraão Village, and along the trail between Abraão and Enseada das Palmas, with deforestation and invasion of grasses covering the hill (Morro do Ferreira). There is herbaceous vegetation dominated by the grasses "capim sapê" Imperata brasiliensis and "capim-gordura" Melinis minutiflora. Specific focus on these invasions would need a specific detailed study. Fig. 2 shows the distribution of the landscape units in the Park.

Analyzing the data available between 1966-1991, we concluded that the dense Atlantic forest lost 48 hectares in that period while the secondary forest was recovering an additional 273 hectares. The analysis of IBGE maps and the evolution of forest losses due to manmade deforestation seen on satellite images shows that the particular situation of the vegetation cover on Ilha Grande is significantly better than the overall degradation of the Atlantic Forest in general. In the region of the municipality of Angra dos Reis (including Ilha Grande) the loss of forest in the period 1985-1990 was 189 hectares while in the period 19901995 it was 1,352 hectares. Relatively the loss on Ilha Grande was significantly small. The Atlantic forest remnants in the same area in 1985 were estimated by SOS Mata Atlântica to be of 96,879 hectares, while in 1990 the figure was 96,690 and 95,338 hectares in 1995 (SOS Mata Atlântica, INPE and ISA, 1998). The analysis performed using the habitat index (according to the procedure proposed by Hannah et al., 1995) has shown a high index, meaning a good status of the habitat conservation or a low degree of degradation. Table 1 shows that result for the Park compared to the whole situation of the Atlantic forest. 


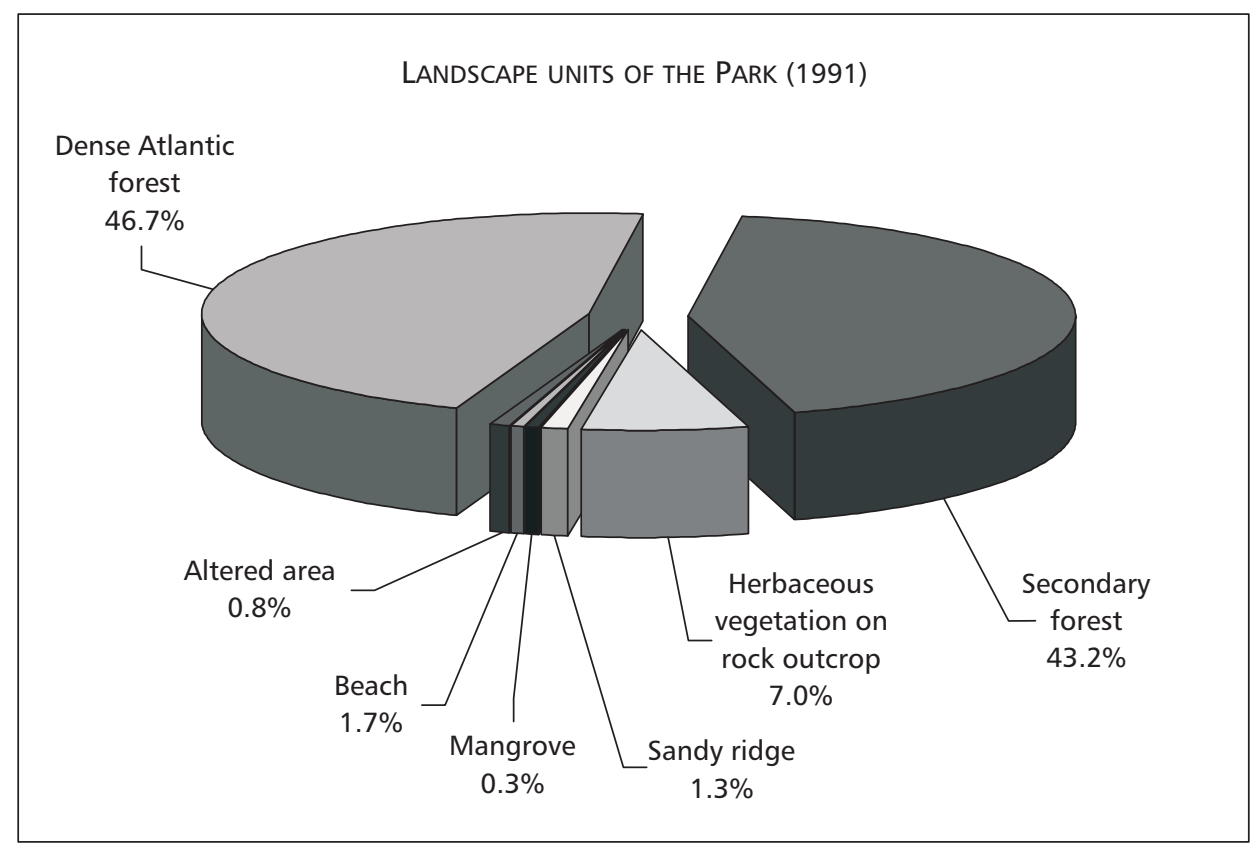

Fig. 2 - Distribution of the landscape units in the Park. (Source: Park Management Directive Plan with data until 1991, UFRRJ/IEF/PRO-NATURA, 1992, complemented with field observation.)

TABLE 1

The conservation status (or degree of disturbance) of the major habitats in the Park compared to the present status of the whole Atlantic forest biome.

\begin{tabular}{|l|c|c|c|c|c|}
\hline & $\begin{array}{c}\text { Total area } \\
\text { (ha) }\end{array}$ & $\begin{array}{c}\text { Non-disturbed } \\
\%\end{array}$ & $\begin{array}{c}\text { Partially } \\
\text { disturbed \% }\end{array}$ & $\begin{array}{c}\text { Occupied } \\
\%\end{array}$ & $\begin{array}{c}\text { Habitat } \\
\text { index }\end{array}$ \\
\hline Park & 4356 & 46.7 & 52.54 & 0.8 & 59.8 \\
\hline Atlantic forest & 2239440 & 6.5 & 24.4 & 69.0 & 12.6 \\
\hline
\end{tabular}

The presence of "embaúba" Cecropia sp. provides the white contrast color of the forest, indicating its secondary growth status. In some areas the "jaguatirão" Miconia theazans is dominant together with the "cobi" Anadenathera colubrina and the "catinga-de-imbê" Casearia sp. In earlier stages of succession the dominant trees are the "cinzeiro" Miconia sp., the "murta" Murcia fallax and the "cupiúba" Trichilia sp. In lower elevations, where the old human habitations used to be, it is common to find introduced fruit trees such as "jaqueira" Arthocarpus integrifolia, "mangueira" Mangifera indica, "amendoeira" Terminalia catappa, "bananeira" Musa spp. among others.

The results of the degree of threat analysis applied to the Park's landscape units (according to the methods employed by WWF, see Olson \& Dinersteins, 1994) show a good status of conservation for the major habitats. Table 2 shows the results. 
TABLE 2

Degree of threat to the natural habitats of the Park.

\begin{tabular}{|l|c|c|c|c|c|c|}
\hline $\begin{array}{l}\text { Kind of } \\
\text { habitat }\end{array}$ & $\begin{array}{c}\text { Overexploitation } \\
\text { biota }\end{array}$ & $\begin{array}{c}\text { Habitat } \\
\text { disturbance }\end{array}$ & Pollution & $\begin{array}{c}\text { Substrate } \\
\text { alteration }\end{array}$ & Total & $\begin{array}{c}\text { Conservation } \\
\text { status }\end{array}$ \\
\hline Dense forest & 10 & 6 & 0 & 4 & 20 & $\begin{array}{c}\text { Relatively } \\
\text { stable }\end{array}$ \\
\hline $\begin{array}{l}\text { Secondary } \\
\text { forest }\end{array}$ & 10 & 17 & 7 & 9 & 43 & $\begin{array}{c}\text { Relatively } \\
\text { stable }\end{array}$ \\
\hline Restinga & 10 & 17 & 7 & 4 & 38 & Vulnerable \\
\hline $\begin{array}{l}\text { Herbaceous } \\
\text { vegetation on } \\
\text { oucky }\end{array}$ & 10 & 17 & 3 & 9 & 39 & Vulnerable \\
\hline $\begin{array}{l}\text { Mangrove } \\
\text { outcrops }\end{array}$ & 10 & 6 & 7 & 0 & 23 & $\begin{array}{c}\text { Relatively } \\
\text { stable }\end{array}$ \\
\hline $\begin{array}{l}\text { Beaches } \\
\text { Human } \\
\text { occupation }\end{array}$ & 10 & 6 & 7 & 4 & 27 & $\begin{array}{c}\text { Relatively } \\
\text { stable }\end{array}$ \\
\hline
\end{tabular}

\section{Biodiversity indicators \\ Mammals}

The field observations indicated two interesting aspects. On the one hand, the presence of the howler monkey Alouatta fusca, a species officially listed as endangered, is a good indicator of well preserved Atlantic forest (Fonseca et al., 1994). On the other hand, the occurrence of the marmoset Challithrix jachus, an introduced species, indicates disturbance since this species is a predator for local bird nests and hatchlings. While the howler monkey prefers moister mature Atlantic forest, feeding on new sprouts, flowers, seeds and fruits of the forest, the introduced marmoset exploit adjacent altered habitats.

Another endangered mammal species seen in the Park was the otter Lontra longicaudis. Arboreal small mammals such as the squirrel Sciurus aestans and the wild rodent Rhipidomys mastacalis occur in the dense forest. In altered areas the presence of the opossum Didelphis aurita is more frequent.

The list of mammal species occurring in Ilha Grande is documented in the literature (UFRRJ/ IEF/PRO-NATURA, 1992) and Hetzel \& Lodi
(1996). We followed the nomenclature employed by Fonseca et al. (1996) and Wilson \& Reeder (1993), as well as the distribution and natural history as described in Emmons \& Feer (1997).

Fig. 3 shows the number of mammal species occurring in the major habitats of the Park as an indicator of the magnitude of the local mammalian diversity. There are 40 mammal species listed for the island (including three introduced). The lowest numbers of species occur in areas occupied by man (11), mostly insectivore bats. The typical mammal fauna of the island is from Atlantic forest, belonging to forest habitats. The high number of species found in mangrove-restinga as well as in the rocky outcrops is due to the transit of forest species through these small transitional areas.

\section{Birds}

The bird indicator species were obtained from UFRRJ/IEF/PRO-NATURA (1992); Coelho et al . (1991) and field observations. Information on habitat sensibility and diet follow Stotz (1996). The taxonomy follows Willis \& Oniki (1991). 


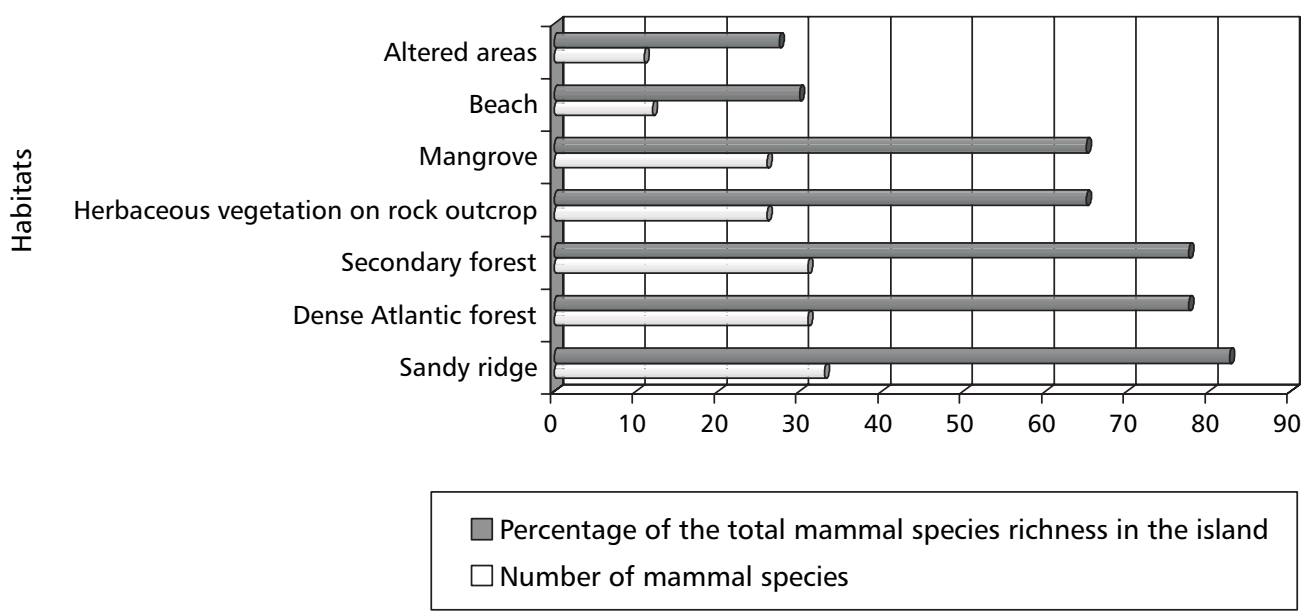

Fig. 3 - Number of mammal species with potential occurrence in different habitats of the Park.

The bird species composition according to the feeding niche (diet) is shown in Fig. 4. Diet is a good indicator and the proportions between omnivores and frugivores are relevant since high numbers of omnivores indicate environmental degradation. This is not the case on Ilha Grande, where a good diet distribution was found, but the absence of toucans
(Ramphastidae) was observed. The distribution of bird species according to stratification of habitats is shown in Fig. 5. In fragmented areas some bird species alter their habitat use and so bird communities occupy less forest strata. In the case of Ilha Grande the local bird community is well distributed in their habitats, indicating a good ecological status.

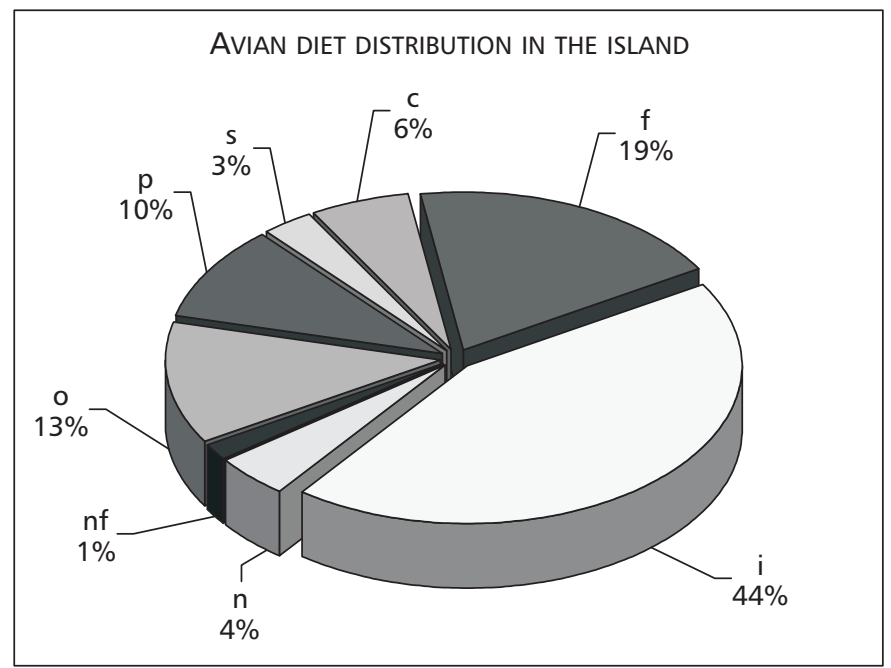

Fig. 4 - Proportions among different avian diets in the island: (i) insectivore, (o) omnivore, (c) carnivore, (n) nectarivore, (f) frugivore, (s) granivore, (nf) necrophagous and (p) piscivore. 


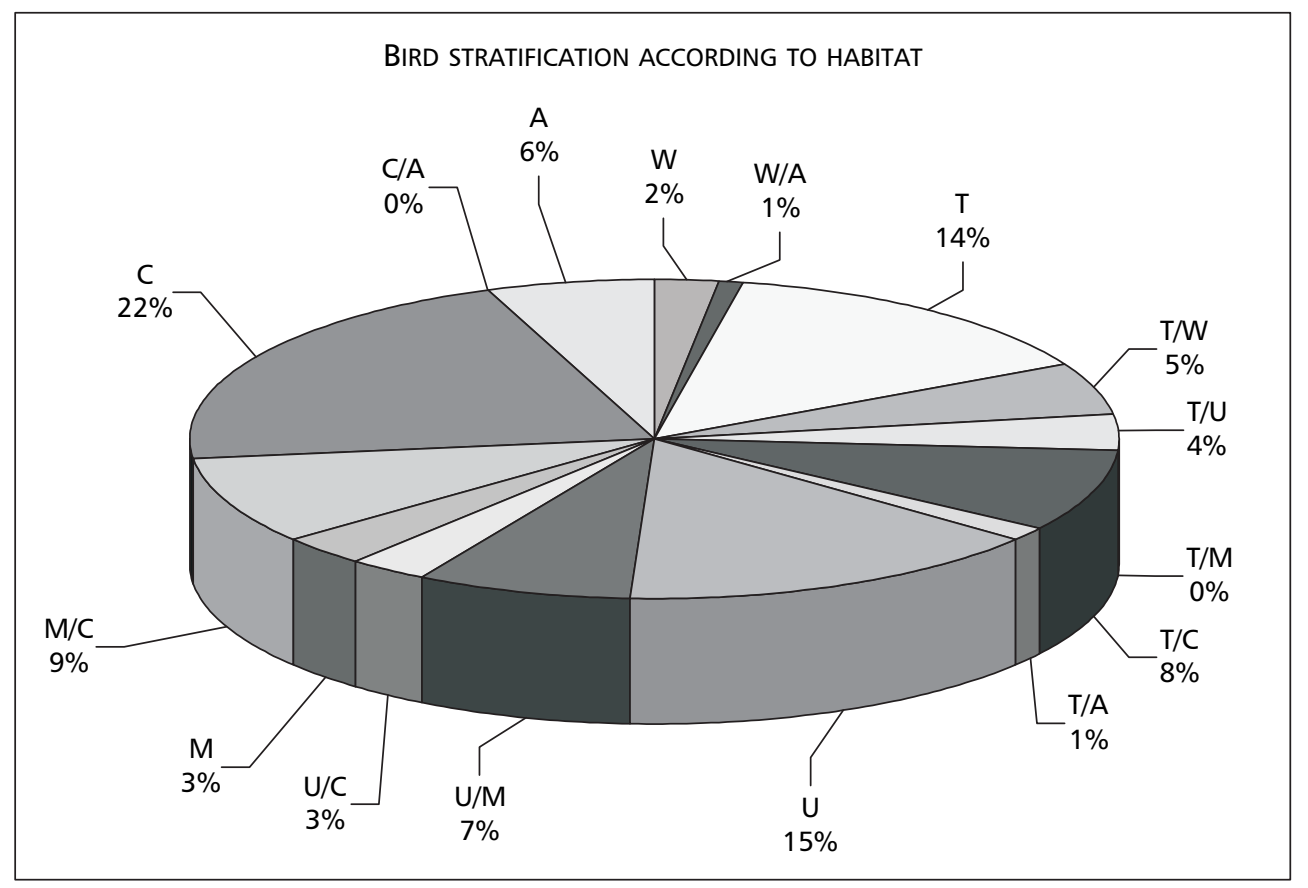

Fig. 5 - Use of different habitat strata by birds: (A) air, (C) canopy, (M) medium stratum, (T) terrestrian, (U) understory and (W) water.

Fig. 6 shows that only $9 \%$ of the bird species have a high sensibility to habitat disturbance while $29 \%$ of the species have a median sensibility. The distribution indicates a stable status of conservation.

The analysis of biotic integrity proposed by Lyons et al. (1995), adapted to bird species showed an apparent biotic integrity for the local bird community.

\section{DISCUSSION}

\section{Historical traits}

The separation of Ilha Grande from the continent is estimated at 7 thousand years (UFRRJ/ IEF/PRO-NATURA, 1992). This fact inspires interest for genetic studies of isolated animal populations. The isolated taxa may be studied under the focus of genetic differences and variation when compared to similar continental taxa. For example, karyotype of wild rodents together with other biological parameters may serve to compare different populations to characterize these populations cytogenetically as well as morphometrically.

The secondary forest is the result of environmental recuperation of the old coffee plan- tations and other crops that existed on Ilha Grande more than a century ago, especially the fazenda Santana which is reported to have had 5 thousand slaves working on the plantations (UFRRJ/IEF/PRONATURA, 1992). The Park was created in 1971. The natural habitat is in a good stage of recuperation, mainly the secondary forest, but it was considered to be vulnerable by the analysis because of the proximity of human occupation and, mainly, because of the expansion of that illegal occupation, as discussed later.

\section{Faunistic indicators}

Mammal species occurred in richer diversity in the dense and secondary forests since the local fauna is typical of Atlantic forest. High occurrence of species in the restinga and rocky outcrops are due to the small size of these transitional habitats. Bird species stratification according to the kind of habitat is well-distributed indicating good status of conservation. The species distribution according to the type of diet is also well distributed, indicating a balanced number of species occupying different feeding niches. The opposite, that is, a larger number of omnivore species, would indicate habitat fragmentation. 


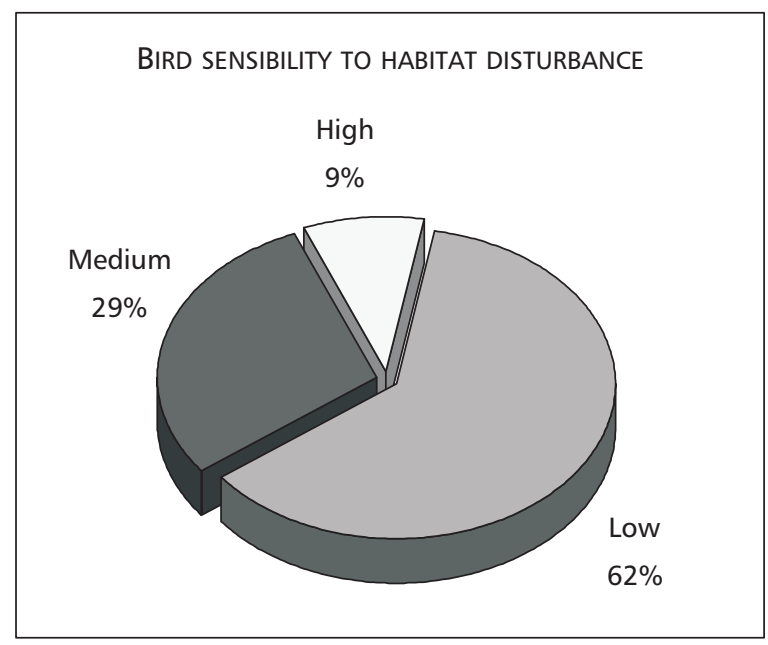

Fig. 6 - Percentage of bird species on the island according to habitat disturbance sensibility.

There are 13 endemic bird species for the Atlantic forest biome occurring on the Ilha Grande, which is also a good indicator for the faunistic integrity. However, the analysis is performed taking the whole number of species registered for Ilha Grande. A more detailed analysis would be necessary to check whether or not a given sensitive species is in decline or not, examining its density, abundance and reproductive success.

\section{Introduced species}

The habitats of the secondary forest show the presence of fruit trees introduced by man. An aspect that merits concern is the invasion of grasses, mainly the "capim-gordura" Melinis minutiflora. This grass is known for displacing native herbaceous vegetation. Some residents set fire to control this grass which represents a threat to the nearby forest.

The presence of introduced rodents (Rattus rattus and Mus musculus) is another concern. It is known that about $95 \%$ of the oceanic islands face problems with these invaders (Lodge, 1993), which follow the human occupation trend. Another aspect to point out is the presence of domestic dogs and cats. These animals have the potential to become feral but no evidence was detected for Ilha Grande. There are cases of the presence of feral dogs in protected areas, like the National Park of Brasília, as well as in non protected islands such as the Isla de Cedros in Mexico (Mellink, 1993).
A controversial introduced species on Ilha Grande is the small monkey Callithrix jachus. Despite being a Brazilian species it occurs outside its distribution range and so it is considered an exotic species for Ilha Grande. Its presence in the state of Rio de Janeiro is not new, and has been known since 1919, when it was brought from the Northeastern region, confiscated by rangers and released in the forest (Coimbra-Filho, 1983). There is an expressive population easily seen in the secondary forest as well as in the dense forest of Ilha Grande. They prey on bird eggs and young birds. A detailed specific study on the impact of this species would be recommended.

\section{Illegal housing: garbage and open sewage}

The increasing number of houses, restaurants and other constructions, especially in Abraão Village and other areas is obvious. This increasing number of all kinds of housing to serve as guesthouses (pousadas), small hotels or even luxurious leisure residences were detected during the field observations and is frequently denounced by the media (see Jornal do Brasil, 2001). Being a protected area, these constructions require the approval of FEEMA (State Foundation for the Environmental Engineering of Rio de Janeiro). Neither the legislation nor the environmental hierarchy of the state authorities has been enforced. By means of a decree of the municipality of Angra dos Reis some bypass permits are allowing this 
irregular and illegal unplanned building growth (see Jornal do Brasil, 2001).

As a consequence, there has been a marked increase in the amount of litter produced by residents and visitors, which is stored in the island's open dump. Some separation of metal and plastic is done for recycling purposes. The organic part attracts vultures and its liquid portion drains into the nearby creek, where the historic waterduct is close to Praia Preta beach. This deposit of garbage constitutes a violation of protected areas, according to the law (Lei de Crimes Ambientais 9.605/98) as well as the forest law (Lei 4.771/65). In addition, there are no sewers nor treatment stations, so all waste goes directly to the creeks and ocean through dark polluted canals locally known as "línguas negras". These can be easily seen in Abraão Village.

\section{Priorities for actions}

During the last century a series of trends changed land use on Ilha Grande. In the past (XVIII and XIX centuries) the expansion of agriculture, especially coffee plantations, predominantly in the lower areas, turned the original Atlantic forest into altered habitats. In 1932 an old hospital to keep immigrants in quarantine (Lazareto) was transformed into a political prison and later on was enlarged (1942), and finally it was demolished in 1994.

Recently the excessive growth of uncontrolled touristic traffic has led to an increasing number of illegal buildings and the disposal of sewage and garbage, including solid waste, into local creeks, with consequent marked water contamination.

Commercial means of collective transportation of visitors and new guesthouses (pousadas) have become so intense that the environmental agencies have lost control, with consequent negative impacts on natural habitats and their associated biodiversity. The same trend can be observed with the illegal number of new houses and camping grounds. During the high season an enormous number of boats and other means of access have been recently observed, facilitating human activities in previously well preserved wild lands, including the ones officially declared as protected areas.

The priority action for the region should be to provide impetus for the development of two major conservation elements that are environmentally appropriate for Ilha Grande: (1) enhancement and enforcement of the officially protected areas and (2) implementation of planned ecotourism.
Additional objectives should be emphasized: (1) management and implementation of infra-structure in order to control contaminants through construction of facilities for water and sewage treatment, and disposal of garbage, to limit creek contamination, to conserve biodiversity, and to improve the quality of life of local traditional villages such as Vila do Abraão; (2) effective management of the officially protected areas to protect landscape units and biodiversity, which are the major tourist attractions; (3) promotion of sustainable activities such as ecotourism and outdoor recreation (4) establishment of sustainable use of resources such as the culture of economically valuable molluscs in small sea farms in order to substitute the decreasing fishing potential through a new economic activity.

On Ilha Grande there are the following officially protected areas: the State Park of Ilha Grande (5,600 hectares) created by decree of the Governor (15273) on June 28, 1971; the State Biological Reserve of Praia do Sul (3,600 hectares) created by gubernatorial decree, state law 4972 of December 2, 1981; the Marine State Park of Aventureiro, created by decree 15983 of November 27, 1990; and the entire area of Ilha Grande $(19,300$ hectares) is declared as na ARIE (Area of Relevant Ecological Interest) according to the State Constitution of Rio de Janeiro (Article 266). In addition, the State decree 9452 of December 5, 1986 declares all islands of the Baía de Ilha Grande in the municipality of Angra dos Reis as protected, integrating the Área de Proteção Ambiental dos Tamoios (Tamoios Protected Areas). The problem is that these officially protected areas are precariously implemented, abandoned without law enforcement and are therefore vulnerable to human activities. One clear example of this conflict is that the Angra dos Reis municipality is allowing new constructions on Ilha Grande but, according to the law, these constructions in officially protected areas should only be authorized by FEEMA (State Foundation for Environmental Engineering). In practice there is an enormous gap between the need for protecting local biodiversity and the actual implementation of the protected areas. A large percentage of Brazil's officially declared protected areas exist only on paper, the so-called "paper parks". The degree of vulnerability of the "paper park" depends upon the degree of implementation the protected area has experienced. 
Acknowledgments - We express our gratitude to Carlos Henrique Abreu Mendes, Augusto Sérgio Guimarães and Vanessa Fernandes Leão (Fundação Pro-Vita) for their support to carry out the project. This work was supported by a contract between the Fundação Pro-Vita and the FNMA (Fundo Nacional do Meio Ambiente of the Ministry of Environment). Celina Alho helped with the preparation of the manuscript. Susan Catherine Casement (Suzy) reviewed the final English version.

\section{REFERENCES}

COELHO, E. P., ALVES, V. S., FERNANDEZ, F. A. S. \& SONEGHET, M. L. L., 1991, On the bird fauna of coastal islands of Rio de Janeiro State, Brazil. Ararajuba, 2: 3140.

COIMBRA-FILHO, A. F., 1983, Situação atual dos calitriquídeos que ocorrem no Brasil (Callitrichidae Primates). pp. 15-33. In: M. T. Mello (ed.), A primatologia no Brasil. Sociedade Brasileira de Primatologia, Belo Horizonte.

EMMONS, L. H. \& FEER, F., 1997, Neotropical rainforest mammals: a field guide. The University of Chicago Press, Chicago, 307p.

FONSECA, G. A. B., RYLANDS, A. B., COSTA, C. R., MACHADO, R. B. \& LEITE, Y. R., 1994, Livro vermelho dos mamíferos brasileiros ameaçados de extinção. Biodiversitas, Belo Horizonte, 459p.

FONSECA, G. A. B., HERRMANN, G., LEITE, Y. L. R., MITTERMEIR, R. A., RYLANDS, A. B. \& PATTON, J., L. 1996, Lista anotada dos mamíferos do Brasil. Occasional Papers in Conservation Biology, 4: 1-38.

GARROD, G. D. \& WILLIS, K. G., 1994, Valuing biodiversity and nature conservation at a local level. Biodiversity and Conservation, 3(6): 555-565.

HANNAH, L., CARR, J. L. \& LANKERANI, A., 1995, Human disturbance and natural habitat: a biome level of a global data set. Biodiversity and Conservation, 4: 128-155.

HETZEL, B. \& LODI, L., 1996, Baleias, botos e golfinhos - Baía da Ilha Grande. Manati, Rio de Janeiro.

JORNAL DO BRASIL, 2001, Crescimento caótico degrada Ilha Grande (First page, Sunday, February 11). Construções irregulares se espalham (Page 18); Depósito de lixo contamina cachoeira (Page 19). Jornal do Brasil, Rio de Janeiro.

LODGE, D. M., 1993, Biological invasions: lessons for ecology. Trends in Ecology and Evolution, 8(4): 133-137.

LYONS, J., NAVARRO-PEREZ, S., COCHRAN, P. A., SANTANA, E. \& GUZMAN-ARROYO, M., 1995, Index of biotic integrity based on fish assemblages for the conservation of streams and rivers in West-Central Mexico. Conservation Biology, 9(3): 569-584.
MACIEL, E. C., ARAÚJO, D. S. D. \& MAGNANINI, A., 1984, Reserva Biológica Estadual da Praia do Sul (Ilha Grande, Angra dos Reis, RJ): contribuição para o conhecimento da fauna e flora. Boletim da FBCN, 19: 126-148.

MELLINK, E., 1993, Biological conservation of Isla de Cedros, Baja California, Mexico: assessing multiple threats. Biodiversity and Conservation, 2(1): 62-69.

OLSON, D. M. \& DINERSTEIN, E., 1994, Assessing the conservation potential and degree of threat among ecoregions of Latin America and the Caribbean: a proposed Landscape Ecology approach. LATEN Dissemination Note \# 10. WWF, The World Bank, Washington, 58p.

PED (Projetos de Execução Descentralizada), 1998, PNMA (Programa Nacional do Meio Ambiente, Ministério do Meio Ambiente), UCE (Unidade de Coordenação Estadual), Rio de Janeiro. Relatórios de atividades: Desenvolvimento Sustentado da Ilha Grande. Componentes: Maricultura, Saneamento, Monitoria, Sistema de Sinalização Turística, Diretiva, Informativa e Educativa das Trilhas da Ilha Grande. Prefeitura de Angra dos Reis, SEMA, Rio de Janeiro, e PNMA, MMA, Brasília.

SOS MATA ATLÂNTICA, INPE (INSTITUTO NACIONAL DE PESQUISAS ESPACIAIS) E ISA (INSTITUTO SOCIOAMBIENTAL), 1998, Atlas da evolução dos remanescentes florestais e ecossistemas associados no domínio da Mata Atlântica no período 1990-1995. Relatório Nacional - Síntese dos Estados do Espírito Santo, Rio de Janeiro, Minas Gerais, Goiás, Mato Grosso do Sul, São Paulo, Paraná, Santa Catarina e Rio Grande do Sul. São Paulo, 54p.

SOS MATA ATLÂNTICA, INPE (INSTITUTO NACIONAL DE PESQUISAS ESPACIAIS) E ISA (INSTITUTO SOCIOAMBIENTAL), 1998, Atlas da rvolução dos remanescentes florestais e ecossistemas associados no domínio da Mata Atlântica no período 1995-1997. Carta IBGE 1:250.000 de Volta Redonda (490) e Rio de Janeiro (491), Estado do Rio de Janeiro. São Paulo, 54p.

STOTZ, D. F., FITZPATRICK, J. W., PARKER, T. A. \& MOSKOVITS, D., 1996, Neotropical birds: ecology and conservation. University of Chicago Press, Chicago, 478p.

UFRRJ (UNIVERSIDADE FEDERAL RURAL DO RIO DE JANEIRO)/IEF (FUNDAÇÃO INSTITUTO ESTADUAL DE FLORESTAS DO RIO DE JANEIRO)/PRO-NATURA (NGO), 1992, Plano Diretor do Parque Estadual da Ilha Grande. Relatório. Rio de Janeiro, 247p.

WILLIS, E. O. \& ONIKI, Y., 1991, Nomes gerais para as aves brasileiras. Gráfica da Região/Sadia S.A., Américo Brasiliense.

WILSON, D. E. \& REEDER, D. M. (eds.), 1993, Mammal species of the world. Smithsonian Institution Press, 1206p. 